\title{
Openness And Inflation: Evidence From Nine Eastern European Nations
}

Rutilio Martinez, University of Northern Colorado, USA Vish Iyer, University of Northern Colorado, USA

\begin{abstract}
Correlation coefficients between inflation and openness were estimated, with data from 1996 to 2010, for Bulgaria, the Czech Republic, Estonia, Hungary, Latvia, Lithuania, Poland, Romania and Ukraine. Eight of the nine coefficients were, as proposed by macroeconomics, negative, although the coefficients for Bulgaria, Estonia, Latvia and Ukraine were not significant. Lithuania's positive and significant coefficient suggested that if openness would not have increased, inflation would have been higher. Cross-country coefficients estimated for 1996, 2000, 2005 and 2010 were negative but not significant due to large differences between the inflation rates of countries that had very similar rates of openness.
\end{abstract}

Keywords: GDP; Imports; Imports/GDP Ratio; Openness; Inflation; Monetary Policy; Soviet Bloc

\section{INTRODUCTION}

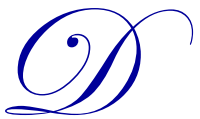

uring the last two decades, several studies, including developed and developing countries, have provided empirical support for the macroeconomic proposition that inflation and openness are inversely correlated (Wynne \& Kersting, 2007, p. 2). These studies, however, have tended to exclude nations that were part of the former Soviet Bloc. In this essay, this macroeconomic proposition is analyzed for nine nations of the former Soviet Bloc; namely, Bulgaria, The Czech Republic, Estonia, Hungary, Latvia, Lithuania, Poland, Romania and Ukraine.

For this analysis, cross-country and per-country correlation coefficients were estimated. The cross-country coefficients were estimated for 1996, 2000, 2005 and 2010, while the per-country correlation coefficients were estimated for the 1996 to 2010 period. The period of the analysis spans from 1996 to 2010 because these were the first and the last years for which complete and reliable data were available. The data used for these estimations consisted of yearly rates of inflation and openness. The rates of growth of the domestic price level were used as the inflation rates, and the rates of openness were measured by the ratio of imports divided by GDP. The data were found in the CIA's "Countries of the World - 28 Years of CIA World Fact Books."

The four cross-country correlation coefficients were negative but statistically not significant. The main reason for this lack of significance was the prevailing high variability between the rates of inflation in countries that had similar rates of openness. Despite this variability, as the negative signs of these coefficients indicate, the countries with the lower (higher) rates of openness tended to have the higher (lower) rates of inflation.

Furthermore, the per-country correlation coefficients for Bulgaria, the Czech Republic, Estonia, Hungary, Latvia, Poland, Romania and Ukraine were also negative. These coefficients were not, however, statistically significant for Bulgaria, Estonia, Latvia and Ukraine. The lack of significance of these coefficients was caused by sharp variations, from year to year, in the rates of inflation in these four nations.

Lithuania had a correlation coefficient that was not only positive, but it was also statistically significant. The unexpected positive sign of this coefficient did not imply that the growing openness caused inflation to increase, but rather that if openness would not have increased, inflation in Lithuania, which increased from 3.1\% in 1996 to $4.7 \%$ in 2010 , might have experienced even larger growth. 


\section{THE THEORETICAL LINK BETWEEN INFLATION AND OPENNESS}

The most common measures of openness are the ratios - exports plus imports divided by GDP and imports divided by GDP. Of these two ratios, only the second one will be used in the discussion that follows because the prices of exports have no influence on the domestic price level, while the prices of imports not only form part of the domestic price level, but as the ratio of imports/GDP increases, the prices of imported goods have a greater participation in the domestic price level.

Imports exert a downward pressure on the growth of domestic prices in three different ways (Wynne \& Kersting, 2007, pp. 8-9). The first of these, and the most direct one, is by increasing the supply of goods in domestic markets where demands for imported goods already exist, or where such demands could be generated once imported goods become available to domestic buyers. This increase, although most visible in domestic markets of consumer goods, would also occur in domestic markets of capital and intermediate goods.

A second way in which imports restrain inflation is by inducing the growth of productivity. This could happen as result of the importation of capital and intermediate goods that are more efficient than domestic capital and intermediate goods, and/or as a result of the intensification of competition in domestic markets that become open to imports. As imports enter domestic markets, domestic producers are likely to see their market shares diminish; thus, to avoid losing market share to imports, domestic producers have basically one option - to become more productive.

Reallocation of resources is the third way in which imports help restrain the growth of domestic prices. When domestic producers shut down or reduce their operations because they could not compete with imports, the labor and capital that they stop using are very likely to be idle for some time. In the long run, however, some or even a good share of the resources idled by imports will be used to produce goods that either do not compete with imports or that have the price and quality needed to compete with them. That is, by displacing inefficient producers, imports cause - not immediately, but in the middle and long run - a resource reallocation that generates increases in domestic output that would not have occurred if protectionist measures would not have been removed or reduced.

The downward pressure that imports exert on inflation is, however, limited by the type of monetary policy being pursued by the central bank. If the imports/GDP ratio is growing at the same time that an expansionary monetary policy is being pursued, the inflation rate would not be as high as it would have been without the growing openness; nonetheless, inflation would still increase. So, if an expansionary monetary policy is being pursued, increasing openness would restrain the growth of the rate of inflation, but it would not cause the rate of inflation to decline.

\section{INCOME, INFLATION AND OPENNESS IN 1996 AND IN 2010}

In 1991 when the Soviet Bloc broke up, the countries of this bloc were presumed to have similar levels of economic development; i.e., similar rates of inflation, similar incomes per head, and similar economic infrastructures. At that time, it was also presumed that the societies of these nations had a positive attitude toward a market-oriented economic system. Yet, as can be seen in Table 1, by 1996, significant disparities in income per head, openness, and inflation had already developed across these nine nations. These disparities suggest that five years of post-Soviet policies had been enough to start generating, among these nations, different levels of economic development and, among the societies of these nations, different attitudes toward privatization of the economy.

Five years of post-Soviet policies were not, however, sufficient for any of these nations to catch up with Greece, the country that, at that time, was quite possibly the less prosperous nation of Western Europe. In 1996, Greece had an income per head of $\$ 10,000$, an inflation rate of $8.6 \%$, and an openness rate of $19 \%$ (CIA, 1997). In that year, as can also be seen in Table 1, only Lithuania had a lower inflation rate than Greece, Lithuania and Hungary were the only countries with more openness, and none of them had an income per head that came close to the income per head in Greece. 
Table 1: Income per Head, Rates of Openness and Rates of Inflation in 1996

\begin{tabular}{|l|c|c|c|c|c|c|c|c|c|}
\hline & Bulgaria & Czech Rep. & Estonia & Hungary & Latvia & Lithuania & Poland & Romania & Ukraine \\
\hline $\begin{array}{l}\text { Income } \\
\text { per Head }\end{array}$ & $\$ 3,830$ & $\$ 7,200$ & $\$ 6,460$ & $\$ 5,700$ & $\$ 4,480$ & $\$ 3,500$ & $\$ 4,920$ & $\$ 2,790$ & $\$ 3,650$ \\
\hline Openness & $12.8 \%$ & $17 \%$ & $9.6 \%$ & $24 \%$ & $9.8 \%$ & $20 \%$ & $9.5 \%$ & $9.7 \%$ & $7.5 \%$ \\
\hline Inflation & $122 \%$ & $10.2 \%$ & $47.6 \%$ & $21 \%$ & $25.3 \%$ & $3.1 \%$ & $30 \%$ & $62 \%$ & $381.8 \%$ \\
\hline
\end{tabular}

Source: CIA, World Factbook, 1997

In 2010, Portugal replaced Greece as the Western European nation with the lowest income per head. In that year, Portugal had an income per head of $\$ 23,800$, an openness rate of $32.7 \%$ and an inflation rate of $2.8 \%$ (CIA, 2011). Comparing these figures with the ones reported in Table 2 shows that of the nine former Soviet Bloc nations, the Czech Republic was the only one that was, according to these three variables, more prosperous than Portugal. The other nations, as can also be seen in this table, were not only far less prosperous than Portugal, but they had also developed, between them, big gaps in income per head and in openness.

Table 2: Income per Head, Rates of Openness and Rates of Inflation in 2010

\begin{tabular}{|l|c|c|c|c|c|c|c|c|c|}
\hline & Bulgaria & Czech Rep. & Estonia & Hungary & Latvia & Lithuania & Poland & Romania & Ukraine \\
\hline $\begin{array}{l}\text { Income } \\
\text { per Head }\end{array}$ & $\$ 12,600$ & $\$ 25,100$ & $\$ 18,800$ & $\$ 18,800$ & $\$ 14,500$ & $\$ 15,000$ & $\$ 17,800$ & $\$ 11,500$ & $\$ 6,400$ \\
\hline Openness & $25.7 \%$ & $38.8 \%$ & $38 \%$ & $40 \%$ & $28.4 \%$ & $29.3 \%$ & $20.6 \%$ & $19.2 \%$ & $15.5 \%$ \\
\hline Inflation & $2.7 \%$ & $1.1 \%$ & $-0.4 \%$ & $4.3 \%$ & $-1.2 \%$ & $4.7 \%$ & $3.4 \%$ & $5 \%$ & $16.5 \%$ \\
\hline
\end{tabular}

Source: CIA, World Factbook, 2011

The large income and openness disparities are congruent with differences in the stages of privatization, level of foreign investment received and composition of exports that, by 2010, prevailed between these nations. In Bulgaria, Latvia, Poland, Romania and Ukraine, privatization had either stopped or was moving at a very low pace, foreign direct investment had been minimal and primary products continued to dominate the exports. In the Czech Republic, Estonia and, to some extent, in Hungary, privatization was very advanced or finished, manufactures or high tech goods dominated exports and foreign investment had been substantial (CIA, 2011; The Heritage Foundation, 2013). These differences suggest that 19 years after the break-up of the Soviet Bloc, these countries had developed very different economic structures and that the economic structures of Bulgaria, Romania, Latvia, Lithuania, and especially that of Ukraine, were quite obsolete.

Despite having different economic structures, inflation in eight of these nations declined between 1996 and 2010. In the Czech Republic, this decline was relatively small; thus, it was probably not too difficult for the Czech government to implement the economic policies that lowered inflation. In Bulgaria, Estonia, Poland, Romania, and especially in Ukraine, the decline in inflation was large or very large. Thus, the governments of these countries showed that, although they had not been too successful in adopting policies that generated high rates of economic growth, they had had the political wherewithal needed to implement the unpopular policies that brought down their inflation rates to acceptable levels.

\section{CROSS-COUNTRY CORREALTION COEFFICIENTS FOR 1996, 2000, 2005 AND 2010}

According to the macroeconomic arguments mentioned above, cross-country correlation coefficients between the rates of inflation and openness should be negative. For the years 1996, 2000, 2005 and 2010, as reported in Table 3, these coefficients were, as proposed, negative. However, as is also reported in this table, these coefficients were not statistically significant.

Table 3: Cross-Country Correlation Coefficients

\begin{tabular}{|l|c|c|c|c|}
\hline \multicolumn{1}{|c|}{ Year } & $\mathbf{1 9 9 6}$ & $\mathbf{2 0 0 0}$ & $\mathbf{2 0 0 5}$ & $\mathbf{2 0 1 0}$ \\
\hline Correlation: & -0.473 & -0.579 & -0.527 & -0.615 \\
Inflation Rate and Imports/GDP & $(0.1986)$ & $(0.1023)$ & $(0.1448)$ & $(0.078)$ \\
\hline
\end{tabular}

Numbers in parentheses are the p-values of the t statistics of the estimated correlation coefficients.

Statistically, the lack of significance of the cross-country correlation coefficients could be attributed to the relative high variability of the rates of inflation across nations with similar rates of openness. An example of this 
situation in 1996 is given by Poland and Romania. In that year, Poland's rates of openness and inflation were, respectively, $9.5 \%$ and $30 \%$, while Romania's were $9.7 \%$ and $62 \%$. Another example of the same situation, this one from 2005, is given by Hungary and the Czech Republic. In 2005, Hungary's rates of openness and inflation were $39.3 \%$ and 7\%; while the corresponding rates for the Czech Republic were 39.6\% and 3.2\% (CIA, 1997, 2011).

Poland and Romania had very different inflation rates, even though they had almost identical rates of openness because Poland's economic infrastructure, although obsolete by Western European standards, has been, and continues to be, significantly less inefficient than that of Romania. In the case of the Czech Republic and Hungary, by 2005 Hungary had the second highest level of income in this group of nine nations, yet its economic structure was, and still is, far less productive than the one of the Czech Republic. That is, the cross-country correlation coefficients lacked significance because marked differences in economic structures, and hence in the levels of economic development, caused countries with very similar rates of openness to have very different rates of inflation.

\section{PER-COUNTRY CORRELATION COEFFICIENTS 1996-2010}

Between 1996 and 2010, the rates of openness increased smoothly, or fairly smoothly, in all nine former Soviet Bloc nations while, with the exception of Lithuania, the rates of inflation rates declined. In the Czech Republic, Hungary, Poland and Romania, this decline followed a rather smooth path, but in Bulgaria, Estonia, Latvia and Ukraine, this decline was marked by sharp swings from year to year. Given these patterns of increase in openness and, with the exception of Lithuania, decline in inflation resulted, as can be seen in Table 4, in negative correlation coefficients for eight of these nine nations and a positive correlation coefficient for Lithuania.

Table 4: Correlation between the Rates of Inflation and Openness for Each Country 1996 to 2010

\begin{tabular}{|c|c|c|c|c|c|c|c|c|c|}
\hline & Bulgaria & $\begin{array}{l}\text { Czech } \\
\text { Rep. }\end{array}$ & Estonia & Hungary & Latvia & Lithuania & Poland & Romania & Ukraine \\
\hline $\begin{array}{l}\text { Correlation: } \\
\text { Inflation and } \\
\text { Imports } \\
\text { /GDP }\end{array}$ & $\begin{array}{c}-0.314 \\
(0.2546)\end{array}$ & $\begin{array}{c}-0.559 \\
(0.0378)^{* *}\end{array}$ & $\begin{array}{c}-0.497 \\
(0.059)\end{array}$ & $\begin{array}{c}-0.692 \\
(0.006)^{*}\end{array}$ & $\begin{array}{c}-0.345 \\
(0.2272)\end{array}$ & $\begin{array}{c}0.682 \\
(0.007)^{*}\end{array}$ & $\begin{array}{c}-0.541 \\
(0.0458)^{* *}\end{array}$ & $\begin{array}{c}-0.617 \\
(0.0188)^{* *}\end{array}$ & $\begin{array}{c}-0.34 \\
(0.2148)\end{array}$ \\
\hline
\end{tabular}

Numbers in parentheses are the p-values of the $\mathrm{t}$ statistics of the estimated correlation coefficients. * Significant at the one percent level. $* *$ Significant at the five percent level.

As a result of the sharp swings in inflation in Bulgaria, Estonia, Latvia and Ukraine, the correlation coefficients for these nations were not statistically significant. The swings in the rates of inflation in these four countries suggest that the governments of these nations were less efficient than the governments of other four countries in dealing with political opposition to the restrictive monetary and fiscal policies that had to be implemented in order to lower inflation.

The positive sign of the correlation coefficient for Lithuania contradicts what macroeconomic theory proposes. This contradiction can, however, be explained. As Lithuania, like the other eight nations, moved away from a centrally planned economy, openness had to increase and inflation had to decline. Openness did increase; it went from $20 \%$ in 1996 to $29.3 \%$ in 2010, but since inflation was already at a low $3.1 \%$ in 1996 , it would have been quite difficult for the Lithuanian government to implement monetary and fiscal policies that would have further diminished inflation. The $3.1 \%$ rate of inflation, however, allowed the Lithuanian government to implement monetary policies that, although not expansionary, were not restrictive enough to preclude inflation from experiencing yearly swings and reaching a level of $4.3 \%$ in 2010 (CIA, 1997, 2011). The increase in inflation from $3.1 \%$ in 1996 to $4.3 \%$ in 2010 was therefore the result of monetary policies that were not as restrictive as they should have been, rather than the result of growing openness.

\section{CONCLUSIONS}

Between 1996 and 2010, openness in these nine nations went from an average of $13.32 \%$ to an average of $28.39 \%$, while income per head increased $75 \%$ in Ukraine and more than doubled in the other eight nations. So, during this period, the share of imports in the aggregate supply of these nations experienced a large increase, which 
implies that the prices of imported goods became more prominent in the consumer price index of each one of these nations. During the same period, inflation increased marginally in Lithuania, but it underwent large or very large declines in the other eight nations. Thus, although none of the cross-country correlation coefficients and only four of nine per-country correlation coefficients were negative and significant, it seems appropriate to conclude that openness was an important cause of the decline in inflation in eight of these nations and that it helped to restrain the growth of inflation in Lithuania where inflation experienced a marginal increase.

Using income per head as a yardstick of prosperity, the three most prosperous nations of this group of nations are the Czech Republic, Hungary and Estonia; while the two least prosperous are Romania, and by far, Ukraine. Respectively, these are also the countries with the three most open and the two least open economies. Openness, it appears, not only contributed to the reduction of inflation, but it might have also played an important role in the promotion of economic growth.

\section{AUTHOR INFORMATION}

Rutilio Martinez is an associate professor of statistics and international business at the Monfort College of Business of the University of Northern Colorado. He has written several papers about the economies of Latin America and has taught a class that deals with the economies and managerial cultures of Latin America in universities in Germany, Lithuania and the Czech Republic. E-mail: rutilio.martinez@unco.edu (Corresponding author)

Vish Iyer is a professor of marketing at the Monfort College of Business of the University of Northern Colorado. He has published more than 20 papers. He organizes and leads a popular yearly student trip to Europe. He has also been in charge of a federally supported academic exchange agreement that includes six universities, two in Canada, two in the U.S.A. and two in Mexico. E-mail: Vish.Iyer@unco.edu

\section{REFERENCES}

1. $\quad$ CIA. (1997). World factbook. Retrived July 17, 2013 from www.umsl.edu/services/govdocs/wofact97/country-frame.html

2. CIA. (2011). Countries of the world- 28 years of CIA world factbooks. Retrieved September 8, 9, 13, 19, 21 and 29; and October 4, 2011 from www.geographic.org/countries/countries.html

3. CIA. (2011). World factbook. Retrived October 18 and 19, and November 11, 2012 from http://www.cia.gov/library/publications/the-world-factbook/geos/ee.html

4. The Heritage Foundation (2013). The 2013 index of economic freedom. Retrieved May 15, 2013 from www.heritage.org/index/ranking

5. Wynne, M., and Kersting, E. (2007). Openness and Inflation. Staff Papers, Federal Reserve Bank of Dallas, No.2, April. 


\section{NOTES}

